\title{
Developments in Solar Powered Agricultural Sprayers: A Review
}

\author{
R. B. Pawar ${ }^{1 *}$, R. T. Ramteke ${ }^{2}$ and S. N. Solanki ${ }^{3}$ \\ ${ }^{1}$ Department of FMPE, ${ }^{2}$ Department of EOES, ${ }^{3}$ Department of FMPE, \\ CAET, Parbhani, VNMKV, India \\ *Corresponding author
}

\section{A B S T R A C T}

\begin{tabular}{|l|}
\hline Ke y w or d s \\
Solar Power, \\
Agricultural \\
Sprayers \\
\hline Article Info \\
\hline Accepted: \\
18 November 2020 \\
Available Online: \\
10 December 2020 \\
\hline
\end{tabular}

Spraying of pesticides is an important task in agriculture for protecting the crops from insects. Farmers presently using hand operated or fuel operated knapsack sprayers for this task. This paper discussed about different types of solar sprayers developed by several researchers with an aim to reduce human drudgery while spraying in field and as part of pollution free and environment friendly green energy. Some advantages and drawbacks of solar sprayers have been identified, discussed and future need of research in line of development of green technologies have been presented in this paper. Comprehensive solution towards solving future energy needs of agriculture is attempted in this study. Spraying is not a continuous operation round the year. So, the same PV system available in solar sprayers can be utilized for energizing other farm operations such as pumping, farm lighting etc. One of the factors which affect the use of conventional electricity or fuel is increasing prices and its non-availability at peak time in rural area. The available solar sprayers used by the farmers are having low field coverage capacities, creating health hazards due to direct inhaling of spray drift and thus, polluting the environment with engine operated sprayers. Therefore, the emphasis should be given on design and developing independent renewable power source which can give uninterrupted energy and fulfill energy demand of remotely located farmers for operating various farm equipments.

\section{Introduction}

In agriculture, considerable amount of energy is used to perform different field activities e.g. ploughing, irrigation, intercultural operations, spraying of agricultural chemicals, harvesting and post-harvest processing etc. Energy security of a country is very important and efforts are being made for utilization of renewable energy sources mainly solar energy, as the fossil fuel based energy is depleting at a very fast rate.
Spraying of pesticides is an important task in agriculture for protecting the crops from insects. Approximately, 18-25\% of the crop production is damaged if pest and diseases are not controlled at right time. Uniform spraying of liquid formulations throughout the crop field is very important for effective control of pest and diseases. Using sprayer, liquid pesticide formulations are generally broken down to minute droplets of effective size for uniform distribution over a large surface area. Dose of agricultural chemicals also plays a 
critical role since under dose may not give the desired coverage whereas overdose is expensive and may contaminate the food chain through residues. Farmers mainly use hand operated or fuel operated knapsack sprayers for this task. Sprayer is a machine to apply herbicides, fungicides, and insecticides in the form of droplets. Among the others lever operated knapsack sprayer, power sprayer and manually operated sprayers are commonly used by small to medium farmers. These conventional sprayer causes user fatigue due to excessive bulky and heavy construction. The traditional knapsack sprayer causes user tiredness due to continuous operation of lever and movement in the field with heavy load on its back.

Considering the above requirements, this review paper discussed about different types of solar sprayers developed by several researchers with an aim to reduce human drudgery while spraying in field carrying conventional sprayer on user's back, few researchers have also designed and developed vehicle for carrying the sprayer.

The design of solar PV sprayer and developments in solar powered agricultural sprayers is discussed and reviewed in detail under this study.

\section{Layout and working principle of solar spraying system}

The energy generation from PV system in a sprayer system and the actual chemical application is explained in block diagram (Fig. 1).

The solar powered agricultural sprayer has following components:

Tank

Solar power unit

i. Solar panel ii) Charge controller

iii) Battery

DC motor/pump

Spraying unit

i) Spray boom

ii) High pressure spray pipe

iii) Nozzles

The selection of the components can be done as per requirement. Tank is used to store the pesticide/insecticide chemical solution. It supplies chemical solution to nozzles on boom through dc motor/pump and pressure pipe.

The solar power unit is energy conversion unit. Solar energy obtained from sun is converted into electrical energy using solar panel by photovoltaic effect. The output of the energy conversion is given to charge a deep cycle lead acid battery through a charge controller.

The charge controller limits the rate at which electric current is added to the battery. Thereby, preventing overcharging and protecting against over voltage. It employs the Pulse Width Modulation (PWM) technique which gradually stops charging the battery, when it exceeds a set high voltage level and gradually re-enables the charging, when the battery voltage drops back below the safe level.

The main advantage of PWM is that the power loss in the switching device is very low. The output from the charge controller is given to the battery by a three pin socket through an electrical network. This circuit is designed to control the RPM of the motor by controlling the amount of resistance between the motor and the battery while simultaneously providing a charging supply for the battery. DC motor/pump lifts the pesticide from tank and delivers to nozzles with desired high pressure. Energy is supplied 
to DC motor/pump by the solar power unit for its running/operation. Nozzles on the boom atomize the spray liquid into fine droplets and sprayed on the crop canopy. The droplet size and spray pattern depends on pressure and type of nozzle used as per requirement.

\section{Design of solar PV system for spraying unit}

Electrical power: Electrical power is defined as the amount of electric current flowing due to an applied voltage. It is the amount of electricity required to start or operate a load for one second. Electrical power is measured in watts (W) (Patil et al., 2014).

Power $=$ voltage $\mathrm{x}$ current

$\mathrm{P}=\mathrm{V} \times \mathrm{I}$

Where, $\mathrm{P}=$ Power (Watt), $\mathrm{V}=$ Voltage $(\mathrm{V}), \mathrm{I}$ $=$ Current $(\mathrm{A})$

\section{Power conversion efficiency of solar panel}

Efficiency of a solar panel is defined as the ratio of the energy output to the energy input from the sun. The solar cell power conversion efficiency can be calculated by using the relation (Patil et al., 2014),

Power conversion efficiency of panel $=\frac{P_{\text {out }}}{P_{\text {in }}}$

PV Efficiency $(\%)=\frac{\text { output Power (watt) }}{\text { Input Power (watt) }} \times 100$

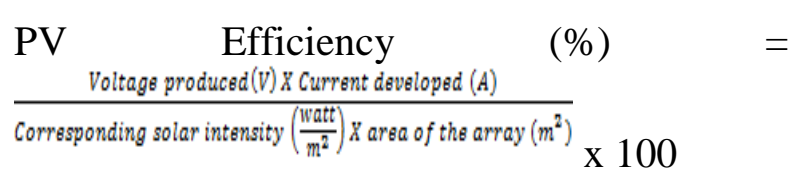

The energy output (watt-hour) indicates the amount of energy produced during the day. Solar cells work best at low temperature as determined by their material properties. All cell materials give less efficiency as the operating temperature rises.
Pumping efficiency: Pumping efficiency is defined as the ratio of power needed to deliver water to the power supplied by the array (Patil et al, 2014).

Pumping Efficiency
$\frac{\text { Power needed to deliver water (watt) }}{\text { Power supplied by array (watt) }} \times 100$

$\left.\frac{\underset{\text { System efficiency }(\%)}{(100} \times \frac{\text { Efficiency }}{\text { Pump efficiency }(\%)}}{100} \times 100\right)=$

\section{Power requirement for pump}

According to head and discharge requirement, capacity of spray pump is selected by following formula (Narete et al., 2016)

$\mathrm{P}=\frac{\rho, g \cdot Q \cdot H}{1000 \cdot \eta}$

Where,

$\mathrm{P}=$ Power required to drive the pump, Watt.

$\rho=$ Density of the liquid, $\mathrm{kg} / \mathrm{m}^{3}$ (Density of water $=1000 \mathrm{~kg} / \mathrm{m}^{3}$ )

${ }^{g}=$ Acceleration due to gravity, $9.81 \mathrm{~m} / \mathrm{sec}^{2}$

$Q=$ Flow or liquid discharge, $\mathrm{m}^{3} / \mathrm{sec}$

$\mathrm{H}=$ Total pump head, $\mathrm{m}$

$\eta=$ Overall efficiency of the pump (Assume it is $60 \%$ )

Flow rate $(\mathrm{Q})$ was determined by (Patil et.al, 2014)

$Q=A \times V=a \times v$

Where,

$\mathrm{Q}=$ Flow rate $\left(\mathrm{m}^{3} / \mathrm{sec}\right)$

$\mathrm{A}=$ Area of cross section of pipe $\left({ }^{m^{2}}\right)$

$\mathrm{V}=$ Velocity of flow in pipe $(\mathrm{m} / \mathrm{sec})$

${ }^{a}=$ Area of the nozzle outlet $\left(\mathrm{m}^{2}\right)$ 
${ }^{v}=$ Velocity of the flow at the nozzle outlet $(\mathrm{m} / \mathrm{sec})$

Total pump head $(\mathrm{H})$ was calculated by

$\mathrm{H}=\mathrm{H}_{\text {stat }}+\mathrm{V}_{\mathrm{h}}+\mathrm{h}_{\mathrm{f}}$

Static head $\left(\mathrm{H}_{\text {stat }}\right)$ was determined by

$\mathrm{H}_{\mathrm{stat}}=\mathrm{h}_{\mathrm{s}}+\mathrm{h}_{\mathrm{d}}$

Where,

$\mathrm{H}_{\text {stat }}=$ Static head (m)

$\mathrm{h}_{\mathrm{s}}=$ Static suction head $(\mathrm{m})$

$\mathrm{h}_{\mathrm{d}}=$ Static delivery head $(\mathrm{m})$

Velocity head $\left(\mathrm{V}_{\mathrm{h}}\right)$ was determined by

$V_{h}=\frac{(V s)^{x}}{2 g}+\frac{(V d)^{x}}{2 g}$

Where, $\frac{(\mathrm{V} s)^{2}}{2 g}=$ Velocity head in suction $(m)$

$\frac{(\mathrm{Vd})^{2}}{2 g}=$ Velocity head in delivery $(\mathrm{m})$

$\mathrm{g}=$ Acceleration due to gravity $=9.81 \mathrm{~m} / \mathrm{sec}^{2}$

Velocity at suction $(V s)=\frac{\text { Discharge }}{\text { Area of suction pipe }}$

Velocity at discharge $(V d)=\frac{\text { Discharge }}{\text { Area of delivery pipe }}$

Friction head (hf) was determined by

$h f=\frac{4 f l V^{2}}{d \times 2 g}$

Where,

$h f=$ Head lost in the pipe, $\mathrm{m}$

$f=$ Co-efficient of friction for the pipe

$l=$ Length of the pipe, $\mathrm{m}$

$V=$ Velocity of the flow in the pipe, $\mathrm{m} / \mathrm{sec}$

$g=$ acceleration due to gravity, $9.81 \mathrm{~m} / \mathrm{sec}^{2}$ $d=$ Diameter of pipe, $\mathrm{m}$

Total pump head $(\mathrm{H})$ was determined by

$\mathrm{H}=\mathrm{H}_{\text {stat }}+\frac{(V d)^{2}}{2 g}+\mathrm{hf}$

Where, $\mathrm{H}=$ Total pump head, $\mathrm{m}$

According to head, discharge and power, matching pump is selected from market. Voltage rating and current of the selected pump is used for selection of battery.

\section{Selection of battery}

According to power and voltage required for running the pump, battery is selected

Battery current rating in Ah $(\mathrm{I})=$ Power $(\mathrm{P})$ for running pump in watt / Voltage $(\mathrm{V})$

\section{Selection of solar panel}

According to battery output power and effective sunshine hours, solar panel is selected. When the battery is connected to the solar panel through charge controller, then some amount of load is applied on solar panel i.e. short circuit.

Actual power of solar panel $=$ Open circuit voltage $*$ Short circuit current

\section{Calculation of current produced by solar} panel and battery charging time

The current produced by the solar panel (I) was calculated by knowing the maximum power $(\mathrm{P})$ of the solar panel and the voltage rating $(\mathrm{V})$ of the battery as follows.

Current produced by solar panel $(\mathrm{I})=$ Max. power of panel(P) / Voltage rating of battery $(\mathrm{V})$ 
Battery charging time (T) was computed by taking the ratio of battery rating in ampere hour (Ah) to the total current (I) supplied by the solar panel.

$\mathrm{T}=$ Battery rating (Ah)/Current supplied by panel (I)

\section{Different designs of solar sprayer}

Joshua et al., (2010) modified existing power sprayer on fossil fuel into solar sprayer (Fig. 2). To overcome the difficulties in the existing model and to reduce the operating cost of the power sprayer, a modified solar sprayer model was designed and introduced for effective operation without fossil fuel. In this modified model, the two stroke petrol engine was replaced by a single motor. This was operated by the electrical energy stored in the $12 \mathrm{~V}$ battery attached in the Unit. The $12 \mathrm{~V}$ battery can be charged by the solar panels. Comparison between existing power sprayer and developed solar sprayer is shown in Table 1 .

This study concluded that, the developed solar sprayer is environment friendly, cost effective, maintenance free and fuel cost was nil.

Patil et al., (2014) evaluated solar operated knapsack sprayer developed using 37 watt solar panel facilitate to operate it on both modes independently i.e. on battery mode and on directly solar panel mode (Fig. 3). Overall model design provides weight of panel as well as weight of sprayer on operator shoulder, which facilitate effortless operation. Sprayer can run 2.5 hours more after 5 hours of operation in full solar intensity. Sprayer is capable of spraying the liquid 360 liter/ha in $4.00 \mathrm{~h}$ at a walking speed of $0.7 \mathrm{~m} / \mathrm{s}$. Discharge rate of sprayer was 0.0267 liter/sec.

Swami et al., (2016) designed and developed a solar PV based sprayer which can be moved in the field with the help of manually drawn vehicle. The developed solar PV sprayer operates both on direct mode and indirect mode. In the direct mode, the sprayer was operated by using electricity generated by 100 Wp polycrystalline PV module mounted on the sprayer and in the indirect mode it was operated on battery mode using stored electric energy in a deep cycle battery (12 V, $32 \mathrm{Ah})$. In both modes, a DC motor pump of $60 \mathrm{~W}$ was used to generate the required operating pressure to spray the liquid pesticide formulations. The brass nozzle, which requires an operating pressure of about 1.5-2 $\mathrm{kg} / \mathrm{cm}^{2}$ to provide a discharge of $900 \mathrm{ml} / \mathrm{min}$ was used in the study. The capacity of the liquid tank 50 liters for an uninterrupted operation for 2 hours with two nozzles.

Performance of the developed solar PV sprayer on manually drawn vehicle has been tested in field and found satisfactory to spray pesticide in different arid crops and the sprayer can be best operated during 9:00 AM to 3:00 PM for Jodhpur station (Fig. 4).

Although, initial cost (Rs. 24,650) of the proposed system is little more as compared to conventional sprayer but the running cost is very less. Further, the system is eco-friendly.

Yallappa et al., (2016) developed and evaluated solar powered sprayer consisting of $20 \mathrm{~W}$ solar panel, 12V DC battery charged by solar energy received by the solar panel, a DC motor operated by the battery, a pump to spray pesticide and a tank to hold the pesticide (Fig. 5). The entire unit is portable and operated by one labour. The discharge rate of the sprayer during laboratory and field conditions were measured, the average discharge rate was about $0.023 \mathrm{l} / \mathrm{s}$.

\section{Performance evaluation of the sprayer}

The performance evaluation of the sprayer was carried out by spraying different crops in 
farmer's fields. The walking speed of the operator was $2.8 \mathrm{~km} / \mathrm{h}$ and the swath width of the sprayer was $0.6 \mathrm{~m}$, which corresponds to theoretical field capacity of $0.17 \mathrm{ha} / \mathrm{h}$. The effective field capacity of the sprayer was observed to be $0.14 \mathrm{ha} / \mathrm{h}$ which corresponds to an average coverage of $1 \mathrm{ha}$ /day of 8 hours operation. It was found quite economical and eco-friendly which can be affordable to small and marginal farmers.

Mishra et al., (2017) developed multi-purpose agricultural machine for spraying (Fig. 6). It works on non-conventional energy source i.e. solar energy. Components of multipurpose agro equipment are fluid tank, spraying pipe, solar panel, batteries, pump, motor, switch \& toggle, frame, ground wheel, front and bottom LED, twin end blower and charging circuit. In this frame, a solar photovoltaic panel is fixed on top rectangular link that converts solar power into electricity. This electricity is provided to the battery via a charging circuit and is used for charging the battery. Battery supplies power to electric motor via control switches, by controlling which entire device can be operated. The pump is driven by DC motor that receives power from the battery. Thus, insecticide in liquid form is sprayed on crops.

Veerangouda et al., (2017) presented a case study on developed bullock-drawn solar powered high clearance sprayer shown in Fig. 7 having tank capacity of 275 litre, ground clearance of $120 \mathrm{~cm}$ and boom length of 450 $\mathrm{cm}$ with 5 nozzles. The average draft required for pulling the cart was $803.50 \mathrm{~N}$. The boom discharge for five nozzles was ranged from 36.5 to $44.5 \mathrm{l} / \mathrm{min}$ during operation.

It was observed that, the cost of operation of bullock drawn solar sprayer was Rs. 128.14 per ha for cotton and Rs. 119.66 for red gram. Breakeven point and payback period were $123.61 \mathrm{~h}$ /annum and 3.6 years. Financial saving over the manual knapsack sprayer was
56 per cent for cotton and 67.1 per cent for red gram crop. Labour saving over knapsack sprayer was 56.6 and 59.48 per cent in cotton and red gram respectively.

Farmers apply poisonous chemicals mostly using manually and power operated knapsack sprayer to protect their crops. The results of the research work carried out by various authors on different solar sprayers are summarized in the respective sections. However, some of the important results are shown in the table 2 and 3 below.

\section{Advantages and drawbacks of existing solar spraying techniques}

Based upon the reviews made in the paper, some advantages and drawbacks of solar sprayers have been identified and discussed. It is observed that, in the manual backpack spraying, the labor has to carry all the weight of the pesticides filled tank which causes fatigue to labor and hence reduces the human capacity. Proper pressure is not maintained, which affects the droplet size and distribution uniformity. Operator is exposed to harmful pesticide spray drift during spraying and operator's safety is at risk.

The existing power knapsack sprayers were converted into solar sprayers by replacing fuel engines with DC motor. The back pain due to vibration was observed during the operation. Operator's safety is a also a question mark, as he is always exposed to harmful pesticide spray drift during spraying. Elimination of harmful exhaust gases may lead to clean environment.

Pushing activity involved in trolley based solar sprayers creates fatigue among the operators. These sprayers also have less field capacity and operators are exposed to chemical as he walks behind the spray pattern. 
Table.1 Comparison between Existing power sprayer and developed solar sprayer

\begin{tabular}{|l|l|}
\hline Existing Power sprayer & Developed solar sprayer \\
\hline Operating system with fuel & $\begin{array}{l}\text { Operating system without fuel (Solar } \\
\text { energy) }\end{array}$ \\
\hline $\begin{array}{l}\text { Working Model: Two Stroke Petrol } \\
\text { Engine with fuel }\end{array}$ & $\begin{array}{l}\text { Working Model: Battery operated } \\
\text { DC motor }\end{array}$ \\
\hline $\begin{array}{l}\text { Unit cost of power sprayer with } \\
\text { engine Rs. 4,000 to 5,000 }\end{array}$ & $\begin{array}{l}\text { Unit cost of power sprayer without } \\
\text { engine } 3900\end{array}$ \\
\hline Operating cost per hour: Rs.70/- to Rs.75/- & Operating cost: Nil \\
\hline Effective Maintenance should be adopted & Maintenance Free \\
\hline
\end{tabular}

Table.2 Technical Specifications of different types of solar sprayers

\begin{tabular}{|c|c|c|c|c|c|}
\hline \multirow{2}{*}{$\begin{array}{l}\text { Sr. } \\
\text { No. }\end{array}$} & \multirow[t]{2}{*}{ Reference } & \multirow{2}{*}{$\begin{array}{l}\text { Type of } \\
\text { sprayer }\end{array}$} & \multicolumn{3}{|c|}{ Technical specifications of solar sprayer components } \\
\hline & & & Motor/Pump & Battery & Solar Panel \\
\hline 1 & $\begin{array}{l}\text { Joshua et al. } \\
\text { (2010) }\end{array}$ & $\begin{array}{l}\text { Modified } \\
\text { solar } \\
\text { sprayer }\end{array}$ & $\begin{array}{l}\text { Power: } 82 \mathrm{~W} \\
\text { Voltage: } 12 \mathrm{~V} \\
\text { Current: } 7 \mathrm{~A} \\
\text { Cost: Rs. } 350 \text { - } 400\end{array}$ & $\begin{array}{l}\text { Power : } 84 \mathrm{~W} \\
\text { Voltage : } 12 \mathrm{~V} \\
\text { Current: } 7 \mathrm{~A} \\
\text { Cost: Rs.500 - } 600\end{array}$ & $\begin{array}{l}\text { Power : } 75 \mathrm{~W} \\
\text { Voltage : } 15 \mathrm{~V} \\
\text { Current : } 5 \mathrm{~A} \\
\text { Cost: Rs. } 700-1000\end{array}$ \\
\hline 2 & $\begin{array}{l}\text { Patil et } \\
\text { al.(2014) }\end{array}$ & $\begin{array}{l}\text { Solar } \\
\text { operated } \\
\text { knapsack } \\
\text { sprayer }\end{array}$ & --- & $\begin{array}{l}\text { Dry lead battery } \\
\text { Voltage: } 12 \text { volts } \\
\text { Capacity: } 7.0 \mathrm{Ah}\end{array}$ & $\begin{array}{l}\text { Power: } 37 \mathrm{~W} \\
\text { Voltage: } 16.4 \mathrm{VDC}\end{array}$ \\
\hline 3 & $\begin{array}{l}\text { Swami et al. } \\
(2016)\end{array}$ & $\begin{array}{l}\text { Trolley } \\
\text { based solar } \\
\text { sprayer }\end{array}$ & $\begin{array}{l}\text { Power: } 60 \mathrm{~W} \\
\text { Volts: } 24 \mathrm{~V} \\
\text { Amps: } 2.5 \mathrm{~A} \\
\text { Discharge: } 5.0 \mathrm{lpm}\end{array}$ & $\begin{array}{l}\text { Voltage: } 12 \mathrm{~V} \\
\text { Current: } 25 \mathrm{Ah} \\
\text { Weight: } 16 \mathrm{~kg} \\
\text { No. of batteries: } 2\end{array}$ & $\begin{array}{l}\text { Power: } 50 \mathrm{~W} \\
\text { Voc: } 21.9 \mathrm{~V} \\
\text { Isc: } 3.18 \mathrm{~A} \\
\text { Module effi.: } 13.1 \% \\
\text { No. of modules: } 2\end{array}$ \\
\hline 4 & $\begin{array}{l}\text { Yallappa et } \\
\text { al. (2016) }\end{array}$ & $\begin{array}{l}\text { Portable } \\
\text { solar } \\
\text { powered } \\
\text { sprayer }\end{array}$ & $\begin{array}{l}\text { Power: } 82 \mathrm{~W} \\
\text { Voltage: } 12 \mathrm{~V} \\
\text { Current: } 7 \mathrm{~A} \\
\text { Speed: } 1600 \mathrm{rpm} \\
\text { Weight: } 1 \mathrm{~kg}\end{array}$ & $\begin{array}{l}\text { Voltage: } 12 \mathrm{~V} \\
\text { Current: } 7 \mathrm{~A}\end{array}$ & $\begin{array}{l}\text { Size: } 0.5 \mathrm{~m} \text { x } 0.3 \mathrm{~m} \\
\text { Peak power: } 20 \mathrm{~W} \\
\text { Voltage: } 17 \mathrm{~V} \\
\text { Weight: } 1 \mathrm{~kg}\end{array}$ \\
\hline 5 & $\begin{array}{l}\text { Veerangoud } \\
\text { aet al. } \\
(2017)\end{array}$ & $\begin{array}{l}\text { High } \\
\text { clearance } \\
\text { bullock } \\
\text { drawn solar } \\
\text { sprayer }\end{array}$ & $\begin{array}{l}\text { HP: } 0.50 \\
\text { Current: } 15.5 \mathrm{~A} \\
\text { Voltage: } 24 \mathrm{~V} \mathrm{Dc} \\
\text { Head: } 10 \mathrm{~m} \\
\text { Discharge: } 25-50 \mathrm{lpm} \\
\text { Speed: } 1500 \mathrm{rpm}\end{array}$ & $\begin{array}{l}\text { Lead acid batteries } \\
\text { Voltage: } 12 \mathrm{~V} \\
\text { Capacity: } 100 \mathrm{Ah} \\
\text { No. of batteries: } 2\end{array}$ & $\begin{array}{l}\text { Power: } 251.9 \mathrm{~W} \\
\text { Current: } 6.99 \mathrm{~A} \\
\text { Voltage: } 36 \mathrm{~V} \\
\text { Module effi.: } 15.3 \% \\
\text { No. of modules: } 2\end{array}$ \\
\hline
\end{tabular}


Table.3 Summary of solar sprayers developed and their performance evaluation

\begin{tabular}{|c|c|c|c|}
\hline S. $\mathbf{N}$. & Reference & Type of sprayer & Research findings \\
\hline 1 & $\begin{array}{l}\text { Joshua et al. } \\
(2010)\end{array}$ & Modified solar sprayer & $\begin{array}{l}\text { Developed a power sprayer with two stroke petrol engine. } \\
\text { Since the operating cost was found high they suggested a } \\
\text { solar operated sprayer. }\end{array}$ \\
\hline 2 & Patil et al.(2014) & $\begin{array}{l}\text { Solar } \quad \text { operated } \\
\text { knapsack sprayer }\end{array}$ & $\begin{array}{l}\text { Evaluated solar operated knapsack sprayer and was } \\
\text { capable of spraying the liquid } 360 \text { liter/ha in } 4.00 \mathrm{~h} \text { at a } \\
\text { walking speed of } 0.7 \mathrm{~m} / \mathrm{s} \text {. Discharge rate of sprayer is } \\
0.0267 \text { liter } / \mathrm{sec} \text {. }\end{array}$ \\
\hline 3 & $\begin{array}{l}\text { Swami et al. } \\
(2016)\end{array}$ & $\begin{array}{l}\text { Trolley based solar } \\
\text { sprayer }\end{array}$ & $\begin{array}{l}\text { Performance of the developed solar PV sprayer on } \\
\text { manually drawn vehicle has been tested in field and } \\
\text { found satisfactory to spray pesticide in different arid } \\
\text { crops and the sprayer can be best operated during 9:00 } \\
\text { AM to 3:00 PM for Jodhpur station. }\end{array}$ \\
\hline 4 & $\begin{array}{l}\text { Yallappa et al. } \\
\text { (2016) }\end{array}$ & $\begin{array}{l}\text { Portable solar powered } \\
\text { sprayer }\end{array}$ & $\begin{array}{l}\text { The theoretical field capacity and effective field capacity } \\
\text { of the sprayer was observed to be of } 0.17 \mathrm{ha} / \mathrm{h} \text { and } 0.14 \\
\text { ha/h respectively at } 2.8 \mathrm{~km} / \mathrm{h} \text { walking speed and } 0.60 \mathrm{~m} \\
\text { swath width. }\end{array}$ \\
\hline 5 & $\begin{array}{l}\text { Veerangouda } e t \\
\text { al. (2017) }\end{array}$ & $\begin{array}{l}\text { High clearance bullock } \\
\text { drawn solar sprayer }\end{array}$ & $\begin{array}{l}\text { Reported field capacity of } 0.945 \mathrm{ha} / \mathrm{h} \text { at an operating } \\
\text { pressure of } 7 \mathrm{~kg} / \mathrm{cm}^{2} \text { and forward speed of } 2.7 \mathrm{~km} / \mathrm{h} \text { in } \\
\text { cotton and red gram. }\end{array}$ \\
\hline
\end{tabular}

Fig.1 Block diagram of spraying system

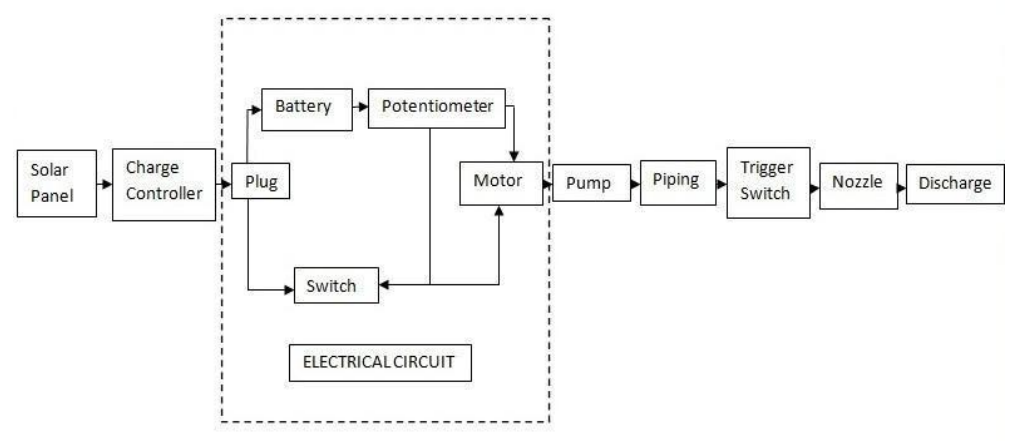

Fig.2 Modified solar sprayer

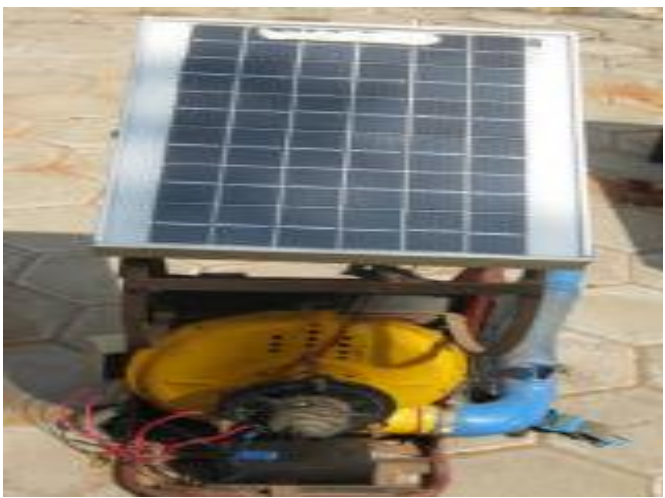


Fig.3 Solar operated knapsack sprayer

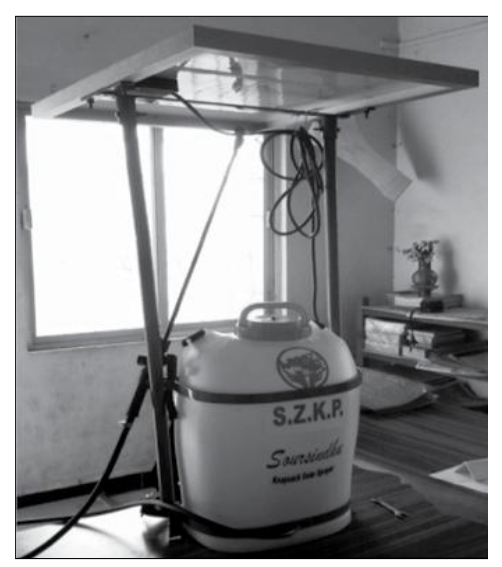

Fig.4 Field evaluation of trolley based solar sprayer

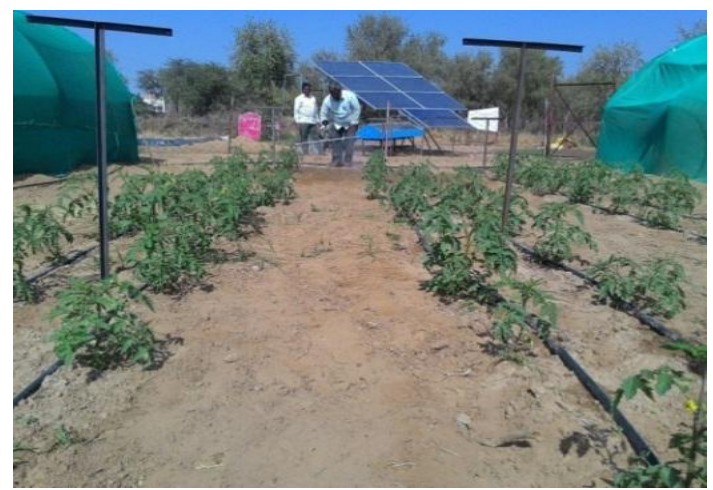

Fig.5 Portable solar powered sprayer

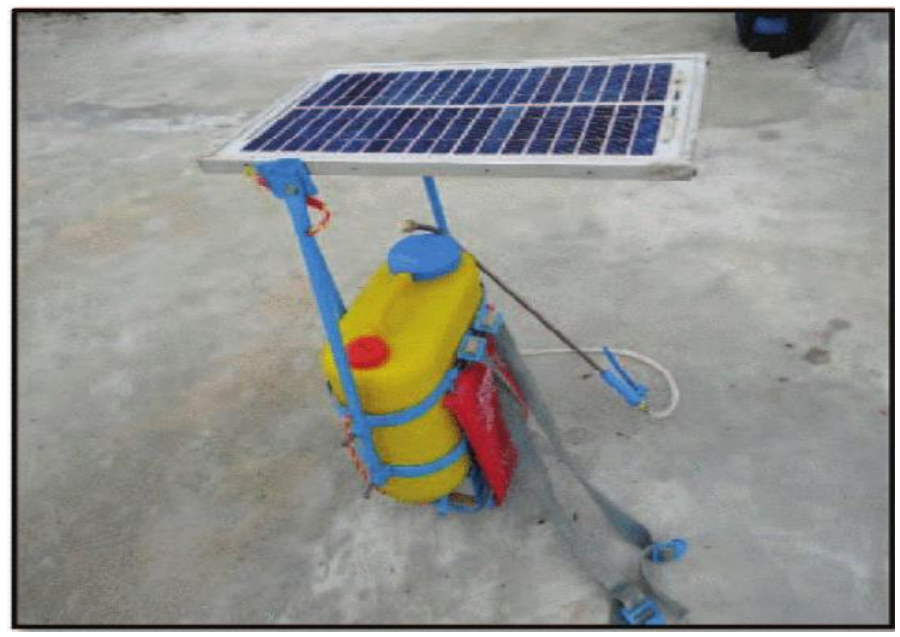


Fig.6 Multi-purpose tool carrier for spraying

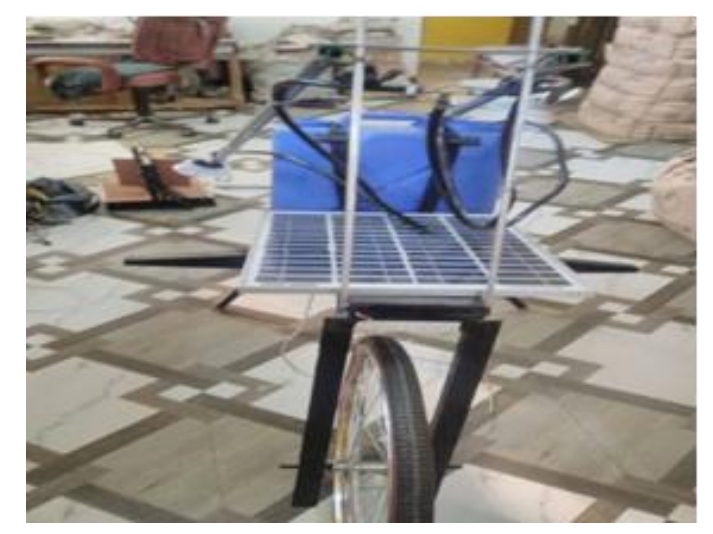

Fig.7 High clearance bullock drawn solar sprayer

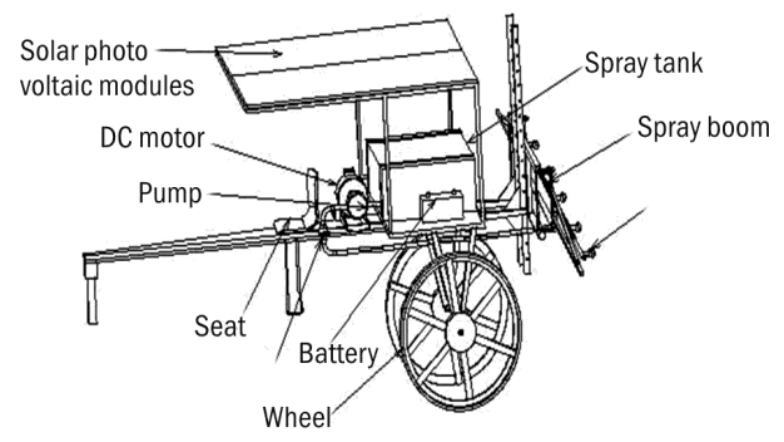

Need of multi-purpose solar cart for spraying and other farm operations

Solar sprayer uses solar power to run sprayer so its operational cost is low, also it is pollution free and environment friendly technology. Most of the solar sprayers are developed by modifying existing knapsack sprayers. Petrol engine of knapsack sprayer is replaced by dc motor and solar PV panel and rest of the working is same. Therefore, it is necessary to design and develop scientific and compact size boom sprayer suitable for major crops and operated by solar energy. Also it should take care of operator's safety and reduces health hazards. Utilization of solar energy for spraying, water lifting and lighting is possible by providing movable solar energy power unit which can perform the important operations on the farm. There is need of such solar power unit with attachment for spraying, water lifting and lighting so as to improve the livelihood of the small and marginal farmers.

There are many farm locations where conventional electricity supplies are not available or at many remote locations, the grid energy has not been reached. It is also difficult for the government to extend the electricity to every location where it is needed for every farmer. Places where the conventional electricity is reached, it is not supplied for sufficient time and frequent power cuts are observed. One of the factors which affect the use of conventional electricity or fuel is increasing prices and its non-availability at peak time in rural area. Hence, there is need of independent alternate 
power source like solar energy that can be used for water lifting at remote places to fulfill the domestic and irrigation needs of the small and marginal farmers.

Spraying is not a continuous operation round the year. So, the same PV system can be utilized for energizing other farm operations such as pumping and farm lighting etc. Looking to the limitations of conventional energy sources, its application issues in agriculture and drawback of existing sprayers in use, a research on development of independent Multi-purpose Solar Energy Cart is desperately needed for spraying and other farm operations.

In conclusion the future, multi nozzle sprayer may be designed by adopting high power motor in the system so that the area coverage will be increased and time and labour requirement may be saved.

The design and development of bullock drawn high clearance sprayer for uniform and effective application, minimum drudgery and operator's safety from hazardous chemicals is essential for different type of field and crop conditions.

An emphasis on substituting conventional energy sources by solar energy techniques should be given because solar energy is free of cost, unlimited, pollution free and environment friendly green energy for agricultural sprayers and other farm operations.

The developed solar energy cart could be utilized for energizing various farm operations other than only spraying activity.

\section{References}

Charvani, S., K. Sowmya, M. Malathi, P. Rajani, K. Saibaba.2017. Design and fabrication of a solar sprayer.
Institute of Electronics and Telecommunication Engineers. IETE: 237-244.

Joshua, R., Vasu, V. and Vincent P. 2010. Solar sprayer- An agriculture implement. International Journal of Sustainable Agriculture (IDOSI Publications) 2(1): 16-19.

Chavan, R., Hussain, A., Mahadeokar, S., Nichat, S. and Devasagayam, D. 2015. Design and construction of solar powered agricultural pesticides prayer. International Journal of Innovations \& Advancement in Computer Science 4(4): 145-150.

Khan, Z. 2014. Unique solar operated sprayjet. IOSR Journal of Mechanical and Civil Engineering (IOSRJMCE):43-46.

Kshirsagar S., Dadmal, V., Umak, P., Munde, G. and Mahale, P.R. 2016. Designand Development of agriculture sprayer vehicle. International Journalof Current Engineering and Technology (INPRESSCO IJCET) 4(March): 405408.

Kulkarni, S., Hasurkar, K.,Kumbhar, R.,Gonde, A. and Raut, A.S. 2015. Review of solar powered pesticide sprayer. International Journal of Research in Advent Technology 3(4):30-33.

Lad, P., Patil, V., Patil, P., Patil, T. and Patil, P. 2015. Solar operated pesticide sprayer. International Journal of Advance Research in Science and Engineering 4(1) April: 122-126.

Mishra, N., S. Khare, S. Singh and M. Dabur. 20117. Multi-purpose agriculture machine. International Journal of Advances in Science Engineering and Technology 5(1): 40-43.

Narate, A. M. and Waghmare, G. 2016.Design and Fabrication of solar operated sprayer for agricultural purpose. National Conference on 
Innovative Trends in Science and Engineering 4(7): 104-107.

Patil, A.P., Chavan, S.V., Patil, A.P. and Geete, M.H. 2014. Performance Evaluation of Solar Operated knapsack Sprayer, Indian Journals 38(3) June: 15-18.

Rao, V.V., Mathapati, S. and Amarapur, B. 2013. Multiple power supplied fertilizer sprayer. International Journal of Scientific and Research Publications 3(8) August.

Sawalakhe, P.V., Wandhare, A., Sontakke, A., Patil, B., Bawanwade, R., and Kurjekar, S. 2015. Solar powered seed sowing machine. Global Journal of Advanced Research 2(4):712-717.

Swami, V., Chauhan, D., Santra, P. and
Kothari, K.2016. Design and Development of Solar PV based Sprayer for Agricultural Use. Annals of Arid Zone 55(1\&2): 51-57.

Veerangouda, M., Prakash, K.V., Jagjivanram and Din, M. 2017. Bullock Drawn Solar Powered High Clearance Sprayer. Akshay Urja June 2017: 3437.

Yallappa, D., V. Palled, M. Veerangouda and sailendra. 2016. Development and evaluation of solar powered sprayer with multi-purpose applications. Institute of Electrical Electronics Engineers IEEE 2016 Humanitarian Technology conference: 927-1-50902432-2/16.

\section{How to cite this article:}

Pawar, R. B., R. T. Ramteke and Solanki, S. N. 2020. Developments in Solar Powered Agricultural Sprayers: A Review. Int.J.Curr.Microbiol.App.Sci. 9(12): 2610-2621.

doi: https://doi.org/10.20546/ijcmas.2020.912.309 